\section{PROPOSED HANDBOOK TO THE BRITISH MARINE FAUNA.}

$\mathrm{TH} \mathrm{E}$ admirable monographs issued under the auspices of the Ray Society, and in Van Voorst's series, by such well-known authorities as Forbes and Hanley, Alder and Hancock, M'Intosh, Allman, Hincks, Brady, Norman, and others, are amongst the most creditable and useful productions of British Zoology, and all naturalists must devoutly trust that there are still others of a like classical nature to follow, and that, for example, Prof. M'Intosh will soon be able to complete his long-expected work on the British Polychæta.

But many Marine zoologists feel that, quite apart from such exhaustive and expensive monographs, and only aspiring to occupy a very much humbler position, there is pressing need of a "pocket" or seaside "Invertebrate Fauna," which could be used in much the same way as the botanists" "Field Flora." It has been suggested to me more than once during the last few years that I would be doing useful work in compiling such a book; and as no one else seems ready or willing to do so, I feel inclined to make the attempt. Some material has already been accumulated for the purpose, but before going further I wish to lay my views before my fellow zoologists, in the hope that they will be kind enough to criticize the scheme and give me the benefit of their advice.

The only existing work of the kind is Gosse's wellknown, and, so far as it goes, very excellent little "Manual of Marine Zoology," but that book does not really meet the present want, as not only is the date of publication $1855-6$, since when the number of genera and species has probably been something like doubled, but also Gosse merely gives the names of the species, while the book I think of would, in order to be of any real use, require to aim at giving a brief but sufficient diagnosis and figure of every British species. I would adopt as "British" the area defined by Canon Norman's British Association Committee in 1887 .

Probably the most convenient form of publication would be some four to six small volumes, each dealing with one or two of the large groups. This would allow of the groups being published as they were ready, not necessarily in zoological order, and would also be convenient for the use of those interested in one set of animals.

There would be definitions--perhaps with occasional analytical tables or keys-of orders, families, \&c., down to and including genera. Under each genus would be given all sufficiently defined species with a brief description of each either in tabular form or in series, as seems most suitable in each case, and with an indication of size, range, and habitat. Many species might be described very briefly in terms of preceding species, the differences merely being pointed out. By simplicity of language, avoidance of unnecessary repetition, and use of contractions it might be hoped that each species could be confined on an average to a couple of lines.

Illustrations would be either in the form of numerous small outline figures on thin paper plates inserted as near as possible to the pages where the descriptions occur, or as small groups of cuts (as in "Gosse") in the text. There would be a figure of the whole animal in each important genus, or small family, and the figures of the species would represent the diagnostic points only, e.g. in the zoophytes there would be a figure in the genus Plumularia of an entire colony, or shoot, while the species pinnata, setacea, catharina, \&c., would be represented each by a small figure showing the pinnx, calycles, or nematophores as the case required.

I shall now give a few examples, taken from different groups, of the method in which the genera and species might be treated, in order that specialists may have the opportunity of judging and criticizing.
I. From Cœlenterata :--Genus Antennularia.

Stems simple or branched; pinnæ verticillate; nema tophores along the stems; gonothecæ axillary, unilateral.

A. antennina, L., stems clustered, usually simple; hydrothecæ separated by 2 joints. 6 to 9 in. high. Gen. distr. deep w.

A. ramosa, Lamk., stems single, usually branched; hydrothecæ separated by $x$ joint only. 6 to 9 in. high. Gen. distr. deep w.

II. From Crustacea :-Family MaIIDAE.

Hyas. Carapace tuberculous, no spines; branches of rostrum not divaricated; second joint of antenna dilated; no teeth beneath last joint of walking legs.

H. araneus, L., carapace not contracted behind postorhital process. 3 in. Common, shallow.

H. coarctatus, Leach, carapace contracted behind postorbital process. $\mathrm{I}$ in. Gen. distr. shallow.

PIsA. Carapace may be tuberculous, with strong postero lateral spine; branches of rostrum divaricated at extremity; second joint of antenna slender; terminal joint of walking legs toothed beneath.

$P$. tetraodon, Leach, carapace with small tubercles antero-lateral margin with 4 spines. 2 in. Rare, S. coast.

$P$. giblisii, Leach, carapace with large rounded elevations, but no tubercles, no spines on antero-lateral margin. Rare, deep w., S. coast.

MAIA. Carapace covered with numerous sharp spines branches of rostrum strongly divaricated; no teeth beneath terminal joint of walking legs.

M. squinado, Latr. 10 in. long. S. and W. coasts of England.

III. From Tunicata:-Family MoLguLIDA:

EUGYRA. Branchial sac with no folds.

E. slutinans. Möll,, circular area on side free from sand.

1 in. Shallow w., gen. distr.

L. globosa, Hanc.. entirely covered with sand. $\frac{1}{2}$ in.

PerA. Bran. s. with 5 folds each side.

P. hancocki, Hrin., matted fibres at poster. end. $\frac{1}{2}$ in. Irish Sea, $20 \mathrm{fms}$.

Molgula. Bran. s. with 6 or 7 folds each side.

$M$. inconspicua, A \& H., 6 folds, sandy, dors. lam. entire, no pap. on stigmata. $\frac{1}{4}$ in.

M. impura, Hel., 6 folds, sandy, small papillæ on edges of stigmata. I in. W. of Ireland, shallow.

M. simplex, A. \& H., few hairs, little or no sand, 6 folds, anus fringed, dors. tub. horse-shoe, aperture to left. $\frac{1}{3}-\frac{3}{4}$ in.

$M$. tubiferc, Örst., 6 folds, anus fringed, dors. tub. horse. shoe, dors. lam. toothed, sandy. I in. E. coast.

$M$. ampulloides, v. Ben., 6 fulds, anus fringed, dors. tub. horse-shoe, 3 bars on fold, dors. lam. entire. I in. E. coast, shallow.

M. socialis, Ald., 6 folds, anus fringed, dors. tub. horseshoe, 4 bars on fold, dors. lam. entire, sandy, gregarious. $\frac{1}{2}$ in. shallow w. S. coast.

M. holliana, $\mathrm{Hrdn}, 6$ folds, dors, tub. serpentif, hairs bat little sand on test. $\frac{3}{4}$ in. W. of Ireland, Io fms.

$M$. occulta, Kupf., 7 folds, dors. tub. horse-shoe, dors. Iam. toothed, whole body sandy. I in. Shallow w. S. and W. coasts.

M. oculata, Forb., 7 folds, siphonal region alone free from sand, and retractile between folds of test. I in. Gen. distr. Shallow w.

MT. capiformis, Hrdn., 7 folds, globular, not attached, no sand. $\frac{3}{4}$ in. S. coast, shallow $w$

$M$. citrin, A. \& H., 7 folds, attached by left side, no sand $\frac{1}{1-\frac{1}{2}}$ in. under st., litt. E. and W. coasts.

Ctenicella, as Molgula, but branchial and atrial lobes laciniated.

C. complanata, A. \& H, 6 folds on left, 7 on right, depressed, attached, sandy, $\frac{1}{4}$ in.

In conclusion, I need scarcely say that I shall be very grateful for suggestions, and, if the work is carried on, for any information from specialists about less known species, and the discrimination of allied forms, and for specimens, and also for references to any descriptions which might be likely to escape my notice.

W. A. HERdMAN.

NO, I 2 IO, VOL. 47] 